\title{
Factors Influencing Competition in the Maize Milling Sector in South Africa
}

\author{
H. A. Mtisi \\ K. K. Govender \\ Regenesys Business School, \\ University of KwaZulu-Natal, \\ University Rd, Westville, 3630, South Africa
}

DOI: https://doi.org/10.36941/mjss-2022-0oo6

Abstract

Although the maize milling industry in South Africa is highly attractive and profitable, new entrants are unsuccessful. Thus, understanding the factors influencing competition is important for developing strategies which can help new entrants to be more resilient and also succeed. A case study of a very successful organization in the industry was conducted using Porters five forces model, to explore the factors influencing competition in the industry. The selected organization employs a differentiation strategy which enables it to constantly improve and introduce new maize meal varieties to serve a wide range of customers. The findings revealed that the selected organization employs resources, capabilities and knowledge in its business processes to sustain its competitive advantage. Thus, it is recommended that firms entering this industry should harmonize internal resources, knowledge, capabilities and external forces to generate a competitive advantage.

Keywords: competition, strategy, maize milling industry

\section{Introduction}

The maize processing sector in South Africa (SA) was deregulated in 1997, based on the rationale that eradication of the 'inefficiencies' in the maize supply structure would result in curtailed margins and increased competition in the sector. However, this did not happen and on the contrary, the retail margins rose from between $20 \%-40 \%$ in the post deregulation era, This was in contrast with what was experienced in the neighboring countries (Zambia and Zimbabwe), who were implementing similar policies at the time.

The objective of deregulating the maize marketing industry in SA was to remove agricultural inefficiencies that impacted competition, as it was assumed that deregulation would enhance competitiveness in the maize processing sector. A ceteris paribus assumption that increased competition would trigger competitive rivalry in the industry, which would consequently reduce the industry margins, since high competitive rivalry can render more competition in an industry, which eventually trims the profit margins of the competing firms (Porter, 1980).

Since the maize miller to retail margins had not dropped after the implementation of deregulations, it is crucial to explore the industry structure, competitive environment and forces that deter new firm entry into the maize milling sector.

A "maize cartel" which included the major corporate millers was uncovered in 2009 and it was 
alleged that these millers colluded to fix the prices of white maize meal (Mncube, 2008). The SA Competition Commission fined the major players in the industry between R98 million - Ribn, and yet today, these millers continue to dominate the industry. Although it is estimated that there are 190 micro maize firms operating in South Africa, almost $87 \%$ of the market is still dominated by 25 mills operated by way of an oligopoly (FPMC,2004; ACB,2013).

Given the fact that, the 1997 deregulation and 2009 cartel prosecution had failed to curtail margins, it became imperative to investigate the forces influencing competition in the maize milling sector. Several studies have attempted to identify why the 1997 deregulation had failed to curtail margins in the industry, but these studies focused exclusively on the noncompetitive behavior at milling operations. Most importantly, some incumbent maize milling firms in SA managed to sustain their competitive advantage, in this dynamic environment. Organization Y, known as the research organization, is an example of a firm that sustained its competitive advantage by continuously exploring new consumer solutions using its capabilities and resources.

It is against the above background, this study attempts to explore the challenges that entrants into the maize milling sector must combat to become competitive, since a thorough understanding of how they combat competitive forces, survive and sustain themselves can shed light on the development of optimal strategies that the new entrants need to pursue, to become competitive.

\section{Literature Review}

\subsection{Overview of the margins in the maize milling sector in South Africa}

Maize is the dominant cereal in South Africa and represents a per person consumption of $61.15 \mathrm{~kg}$, followed by wheat, which has a per person consumption of $58.48 \mathrm{~kg}$ (Maize and Wheat Forum, 2016).

The maize milling sector plays a critical role in providing processed maize products to the majority of the populace in South Africa, who regard it as their staple food. Despite the deregulation of the industry in 1997, the margins have continued to rise (National Agricultural Marketing Council (NAMC). The NAMC reported that the miller-to-retail margins had increased since 2009, especially for super maize meal products. The inflated SAFEX maize-to-maize meal retail margin suggest that retailers and millers are receiving a larger portion of the prices paid by consumers for processed maize products.

The SAFEX maize to maize meal retail margin is described as the differential of the price at which millers procure the maize on the open market and the retail price of maize meal, after considering extraction rate and value of by-products processed. Within the differential lies the profit that can be shared between the miller and retailer. Table 2 below reflects the SAFEX maize -to- retail maize meal margins for the duration 2013 - 2016. From the data in Table 1, it is evident that the SAFEX maize to retail maize meal price differential grew by $32.37 \%$ for the period 2013 . The expansion of SAFEX maize-to-retail maize meal price differential suggests that millers and retailers are collecting greater portion of the price paid by the consumers.

Table 1: SAFEX maize-to-retail maize differential

\begin{tabular}{|l|c|c|c|c|c|c|c|}
\hline Year & $\begin{array}{c}2013 \\
\text { R/ton }\end{array}$ & $\begin{array}{c}\text { Year on } \\
\text { Year \% }\end{array}$ & $\begin{array}{c}2014 \\
\text { R/ton }\end{array}$ & $\begin{array}{c}\text { Year on } \\
\text { Year \% }\end{array}$ & $\begin{array}{c}2015 \\
\text { R/ton }\end{array}$ & $\begin{array}{c}\text { Year on } \\
\text { Year \% }\end{array}$ & $\begin{array}{c}2016 \\
\text { R/ton }\end{array}$ \\
\hline Super maize meal (retail average) & 6140 & 0.81 & 6190 & 16.64 & 7220 & 36.42 & 9850 \\
\hline Maize price (SAFEX average) & 2352 & -19.87 & 1884.6 & 67.41 & 3155 & 32.80 & 4189.9 \\
\hline Price super maize meal /ton @ 62.5\%, extraction & 3763.2 & -19.87 & 3015.36 & 67.41 & 5048 & 32.80 & 6703.84 \\
\hline SAFEX maize/Retail price differential & 2376.8 & 33.57 & 3174.64 & -31.58 & 2172 & 44.85 & 3146.16 \\
\hline
\end{tabular}

Source: Researcher's Calculations based on SAFEX, STATS-SA data

In 2009, the Competition Commission of South Africa uncovered the so-called "maize cartel", which included the research organization, which was accused of price-collusion. However, despite the 
cartel's prosecution, the miller to retail margins kept on expanding. Table 2 which shows the expansion of miller to retail margin, reveals that regardless of the varying production costs scenario, the miller to retail margin continued to expand.

Table 2: Expansion of miller to retail margins

\begin{tabular}{|c|c|c|c|c|c|c|c|}
\hline & 2003 & \multicolumn{2}{|l|}{2009} & \multicolumn{2}{|l|}{2010} & \multicolumn{2}{|l|}{2011} \\
\hline Average monthly retail price (R/ton) & 2963.5 & \multicolumn{2}{|l|}{$4,17 \cdot 7$} & \multicolumn{2}{|l|}{$3,874.30$} & \multicolumn{2}{|c|}{$4,528.20$} \\
\hline Maize as $\%$ of retail Price & $47 \cdot 4$ & \multicolumn{2}{|l|}{51} & \multicolumn{2}{|l|}{39.2} & \multicolumn{2}{|l|}{37.7} \\
\hline Maize (\% of retail) & 33.2 & \multicolumn{2}{|l|}{32} & \multicolumn{2}{|l|}{19.4} & \multicolumn{2}{|l|}{$19 \cdot 5$} \\
\hline Handling and silo storage (\% retail) & 6.6 & \multicolumn{2}{|l|}{6.55} & \multicolumn{2}{|l|}{7.6} & \multicolumn{2}{|l|}{7.2} \\
\hline Distribution and logistics (\% retail) & 10.6 & \multicolumn{2}{|l|}{10.4} & \multicolumn{2}{|l|}{12.25} & \multicolumn{2}{|l|}{10.89} \\
\hline \begin{tabular}{|l|} 
Cost scenario \\
\end{tabular} & & low & High & Low & high & Low & high \\
\hline Conversion costs as $\%$ of retail price & 35.6 & 33.2 & 36.5 & 38.3 & 42.4 & 36.3 & 40.3 \\
\hline Milling (\% retail) & $17 \cdot 9$ & 16.5 & 18.3 & 19.2 & 21.4 & 18.9 & 20.5 \\
\hline Warehousing and transport (\% retail) & $7 \cdot 3$ & 8.17 & 9.11 & $9 \cdot 51$ & 10.51 & 8.22 & 9.11 \\
\hline Capital costs (\% retail) & 10.31 & 8.21 & 9.11 & 9.61 & 10.72 & 9.11 & 10.1 \\
\hline Miller / retail margin (\%) Retail price & 16.9 & 16.97 & $13 \cdot 51$ & 22.21 & 18.22 & 25.91 & 22.11 \\
\hline
\end{tabular}

Source: Adapted from NAMC (2011); Jooste (2012)

Following the 1997 deregulation, maize has been marketed on the Johannesburg stock exchange via SAFEX. It became apparent that, although SAFEX maize prices would fall, the savings incurred from declining maize prices are not extended to the consumers. Table 3 below shows the price movement for the period October 2013 - 2014. Despite the SAFEX wholesale price dropping by $20.23 \%$, the consumer price for $5 \mathrm{~kg}$ of super maize meal went up by $1.27 \%$. This can suggest that, millers and retailers are not extending the savings obtained on dropping wholesale maize prices to consumers.

Table 3: Milled super and special maize: year to year price movements

\begin{tabular}{|l|c|c|c|c|c|c|c|}
\hline \multicolumn{2}{l}{ October } & \multicolumn{2}{|c|}{$\mathbf{2 0 1 5}$} & $\mathbf{2 0 1 4}$ & \multicolumn{2}{c|}{$\mathbf{2 0 1 3}$} \\
\cline { 3 - 8 } \multicolumn{2}{l|}{} & Price R/ton & \% Year on Year & Price R/ton & \% Year on Year & Price R/ton & \% Year on Year \\
\hline maize meal (special) & $\mathbf{2 . 5} \mathrm{kg}$ & $\mathbf{1 5 . 3 6}$ & $\mathbf{1 . 1 2}$ & $\mathbf{1 5 . 1 9}$ & $\mathbf{- 1 . 7 5}$ & $\mathbf{1 5 . 4 6}$ & -7.26 \\
\hline maize meal (super) & $5 \mathrm{~kg}$ & 37.73 & $\mathbf{1 8 . 3 1}$ & 31.89 & $\mathbf{1 . 2 7}$ & 31.49 & $-\mathbf{0 . 5 8}$ \\
\hline SAFEX white maize & & 3159.93 & 68.34 & $\mathbf{1 8 7 7 . 1}$ & $\mathbf{- 2 0 . 2 3}$ & $\mathbf{2 3 5 3 . 2}$ & -3.91 \\
\hline
\end{tabular}

Source: JSE, SAFEX and Statistics SA

\subsection{Overview of the brands and operating margins of key players}

It was reported (FPMC, 2004; ACB,2013), that although there are 190 micro mills in South Africa processing different types of maize meal, an estimated $87 \%$ of the consumer market is still dominated by three major milling firms. The sustained market dominance by the major maize milling firms and the rising miller/retail margins, implies that there is oligopolistic competition, and that the industry is concentrated (Ncube, Nkhonjera and Zengeni, 2016). Table 4 below reveals the market share of the maize milling firms dominating the consumer market in South Africa. 
Table 4: Market share of Major Maize Milling Firms

\begin{tabular}{|l|c|}
\hline Maize milling Firm & Market share \% \\
\hline Premier foods & $\mathbf{2 5 . 5}$ \\
\hline Pioneer foods & $\mathbf{2 5 . 3}$ \\
\hline Tiger brands & $\mathbf{2 2 . 5}$ \\
\hline Total market share of the three maize milling firms & $\mathbf{7 3 . 3}$ \\
\hline
\end{tabular}

Source: SA Advertising Research Foundation (SAARF),2012

According to research conducted by the South African Advertising Research Foundation (SAARF) in 2012, the brands from the top three corporate millers dominated market. The Iwisa and Nyala brand had the largest market share of $22.5 \%$, followed by White Star at $25,3 \%$, and Ace at $22.5 \%$ (Ncube, Nkhonjera and Zengeni, 2016). The dominance of these brands in the consumer market imply that these brands possess some degree of market power.

Table 5 shows the operating profit margins of some of other leading brand in SA, namely, Pioneer Foods and Tiger Brands, for the period 2006 - 2014. It is evident that Tiger Brand's operating margins are much higher, (18.4\%), compared to Pioneer Foods which averaged $8.3 \%$. Tiger Brands capacity to sustain superior margins appear to be associated with the market power of its brands, which give it a competitive edge (Ncube, Nkhonjera, and Zengeni, 2016).

The disparity in operating profit margins between the two leading companies suggests the complication in defining competitive margins in maize milling industry. The capacity of Tiger Brands to sustain higher margins cannot be attributed to the power of its premium brands alone, since the benefits of diversification cannot be ruled out. The advantage of diversification is that certain risks are diversifiable and a poor performance in one portfolio can be offset by good performance in another (NAMC, 2011).

Table 5: Revenue and operating margins of Tiger brands and Pioneer foods

\begin{tabular}{|l|c|c|c|c|c|c|}
\hline \multirow{2}{*}{ Year } & \multicolumn{3}{|c|}{ Tiger Brands } & \multicolumn{3}{c|}{ Pioneer Foods } \\
\cline { 2 - 7 } & (Rooo)Revenue & $\begin{array}{c}\text { OP.Profit } \\
\text { margin \% }\end{array}$ & $\begin{array}{c}\text { Milling \& Baking } \\
\text { profit margin \% }\end{array}$ & (Rooo)Revenue & $\begin{array}{c}\text { OP.Profit } \\
\text { margin \% }\end{array}$ & $\begin{array}{c}\text { Milling \& Baking } \\
\text { profit margin \% }\end{array}$ \\
\hline 2012 & 22771 & 15.3 & 22.0 & 18609 & 6.2 & 9.5 \\
\hline 2011 & 20479 & 15.9 & 22.3 & 16853 & 7.3 & 9.7 \\
\hline 2010 & 19378 & 15.6 & 23.3 & 15731 & 9.3 & 11.8 \\
\hline 2009 & 20643 & 15.5 & 18.5 & 16283 & 7.4 & 10.4 \\
\hline 2008 & 20126 & 13.3 & 12.9 & 14884 & 5.8 & 7.6 \\
\hline
\end{tabular}

Source: Adapted from Maize Report, African Center for Biosafety, 2013

The mode of entry into the maize milling industry in South Africa has been through acquisitions and mergers, initiated by the agro-conglomerates that inherited the storage facilities in SA. Former cooperatives NTK and NWK moved their operations up the maize value chain and are now involved in the manufacturing of consumer goods (Nkhonjera, Ncube and Zengeni, 2016). The potential of these former co-operatives to integrate their activities upstream, through mergers and acquisitions, can enhance the concentration of the industry.

It is against the above brief background of the maize milling industry in SA, that competition within the industry will be explored using Porter's Five Forces Model. This model which is a framework used in appraising competition in the industrial environment (Pitkethly,2003:251), comprises the following: Power of suppliers, Power of buyers, Threat of substitutes, Threat of new entrants, and Competitive rivalry. The five forces vary in their configuration and intensity across different industries and the profitability of an industry is influenced by the interplay of the five forces, 
which consequently shape the competition in the industry.

Although Porter's model is widely adopted, it does have certain limitations, since it is static and externally focused and only links strategy to the external dimensions and ignores the firm's internal capabilities and resources, which also can be basis for competitive strategy (Grant, 1991; Reddy, 2002). In view of the dynamic and turbulent external environment, the internal resources and capabilities of a company, can be a vibrant foundation on which to formulate strategy. Nevertheless, despite these limitations, the researchers choose the Porters five forces model, due to its appropriateness for use in the industry analysis.

For a firm to deliver superior profits, strategy must be developed to mitigate the competitive forces. The generic strategies according to Porter (1980), consists of two dimensions, namely, the strategic target and the strategic advantage, which are depicted in Figure 1 below.

According to Figure 1, strategic advantage can be achieved by adopting either cost leadership or differentiation strategy and the strategies differ between customer segments, product portfolios and geographical areas. The incorporation of strategic targets and strategic advantage give rise to the main strategic alternatives: cost leadership, differentiation and focus.

Differentiation occurs when a firm creates something unique about its products/services that is perceived as valuable by its customers, rather than just presenting lower price (Porter, 1985:120). Differentiation can be generated based on organization-specific skills or distinctive competencies that result in a competitive edge over other organizations. By offering differentiated products, a firm can generate price inelasticity in demand and brand loyalty which can deter entry into the industry (Grant, 2008:241).

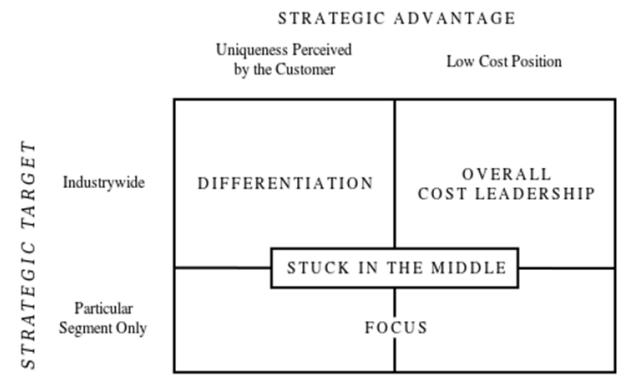

Figure 1: Generic Strategies

Source: Porter, 1985

Cost leadership occurs when a firm engages in cost containment measures to achieve a low-cost structure such that it manufactures and sells its products at a lower price than its rivals (Best, 2008:22). A firm must have a relative high market share, and capacity to reap economies of scale in manufacturing and sales, in order to achieve cost leadership (Grant, 2008:226).

Under a "focus" strategy, management avoids making substantial investment to achieve scale advantages required in serving a huge market. Rather, management pays attention on satisfying a particular segment or segments of the market with unique needs, rather than the mass market (Best, 2008:222). Firms' sometimes are able to develop specialized capabilities in satisfying particular customer segments, with unique demands and needs (Gurau, 2007:371). Focus strategy is aimed at achieving a competitive advantage by offering customized solutions to niche segments of the market on a -narrow scale. The principle underlying this strategy is that it is cost effective for a firm to serve niche segment of the market, rather than to compete on mass market basis (Giannelos, 1988:51).

Value creation in the form of products or services provides customers with utility which can be the basis upon which firms are able to generate a competitive advantage (Porter, 1985). A value chain 
is made up of primary and supporting activities, which include inbound logistics, outbound logistics, support activities, etc, as depicted in Figure2.

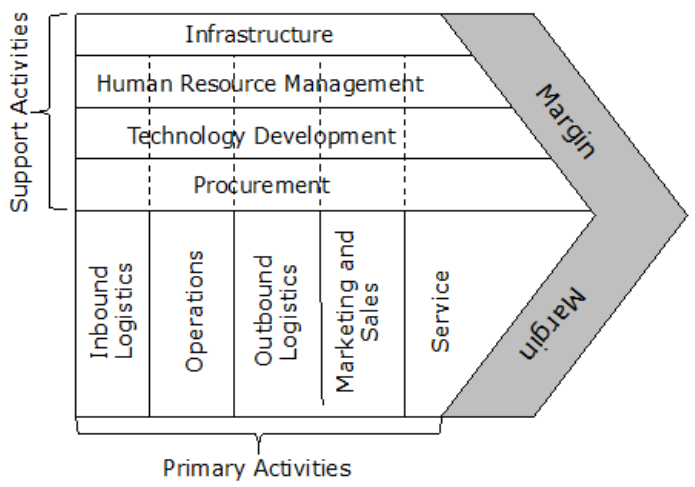

Figure 2: Porter's value chain

Source: Porter, 1985

A firm can gain a competitive advantage by lowering its value chain average costs. A maize milling firm with lower value chain average cost will be able to charge the same market price and make more profit, than risking losing market share by increasing prices. If a maize milling firm has lower unit cost because of benefits of economies of scale, then any cut back in output can raise unit costs.

\section{Research Methodology}

This study employed a mixed method approach to conduct a case study of one of the top three maize milling organizations in SA. The aim was to explore how the research organization, sustains high margins, through competitive advantage, rather than generalize the standardized set of results. A case study research approach was selected because it permitted the researcher to collect first-hand information and details from several sources, to analyze fresh and new data (Yin, 2009).

\section{Research Context}

The rationale for selecting Organization $\mathrm{Y}$, as a single case study was because its business activities, competitive strategies, resources and capabilities have sustained its competitive advantage. Additionally, the organization sustained survival resilience and competitive advantage in the maize milling industry.

The data was collected through in-depth and semi-structured interviews using questionnaires. Six (6) senior staff of the research organization were purposively selected from the head office, of one of the big four maize milling firms dominating the sector in South Africa. The participants were senior staff members with executive accountable for operations, procurement, sales and marketing, quality control, and supply chain and strategy implementation in the firm. The participants who were purposively chosen, based on their capacity and responsibility within the firm, included the marketing director for the grains division, group grains procurement executive, business development executive, plant manager, brand manager and the quality manager. The participants had a combined 70 years of experience in the milling industry; of which 49 years were spent at the research organization. The participants had experience in the following sectors: sales, marketing, commodity broking, consumer products, milling operations, manufacturing, and communication, retail and capital markets. 


\section{Research Instruments}

In-depth and semi-structured interviews were used due to mixed approach adopted in this study. The rationale for employing in-depth and semi-structured interviews using a questionnaire was to allow the participants enough time to respond and at the same time address issues that arose on the topic under discussion during interviews. Depending on the interviewees' responses, the researcher adapted the questions for successive interviews to solicit more relevant information. This was a flexible approach that allowed the researcher to extract deep details (Gubrium \&Holstein, 2001).

To facilitate question design and time control, pilot interviews were conducted as a prerequisite to the interview protocol development (Yin, 2009). The pilot interviews enhanced the reliability of this study, as the themes emerging from the pilot study were used to revise and refine the questionnaire accordingly.

To allow the respondents sufficient time to prepare appropriate documents and information, the researcher emailed the interview questions to respondents prior to the interviews. To minimize bias, the oral responses were audio recorded and notes were also taken for interpretation purposes. According to Creswell (2009), audio recording and note taking are useful tools to improve the reliability and value of the data.

After interviewing the respondents, the responses to the open-ended questions were transcribed and where necessary, to gain further insights and better comprehension of the data, additional information was solicited from interviewees through emails or online interviews. To enhance the reliability of this study, the interview transcripts, including other information gathered, was sent to the interviewees for verification.

\section{Research Findings}

The rating of the strength of competitive forces by respondents, is reflected in Table 6.

Table 6: The Strength of the Competitive Forces

\begin{tabular}{|l|c|c|c|c|}
\hline Competitive Force & Low & Med & High & Total \\
\hline Threat of new entrants & $60 \%$ & $20 \%$ & $20 \%$ & $100 \%$ \\
\hline Bargaining power of buyers & $40 \%$ & $40 \%$ & $20 \%$ & $100 \%$ \\
\hline Bargaining power of suppliers & $0 \%$ & $20 \%$ & $80 \%$ & $100 \%$ \\
\hline Threat of substitutes & $60 \%$ & $40 \%$ & $0 \%$ & $100 \%$ \\
\hline Competitive rivalry & $20 \%$ & $60 \%$ & $20 \%$ & $100 \%$ \\
\hline
\end{tabular}

The participants were requested to rank the competitive forces in order of their importance to the maize milling sector and the findings are captured in Table 7.

Table 7: Ranking of the Importance of Competitive Forces

\begin{tabular}{|l|c|c|c|c|c|c|}
\hline Competitive Force & $\mathbf{1}$ & $\mathbf{2}$ & $\mathbf{3}$ & $\mathbf{4}$ & $\mathbf{5}$ & Total \\
\hline Threat of entrants & $\mathrm{o} \%$ & $\mathrm{o} \%$ & $40 \%$ & $40 \%$ & $20 \%$ & $100 \%$ \\
\hline Bargaining power of buyers & $\mathrm{o} \%$ & $\mathrm{0} \%$ & $60 \%$ & $40 \%$ & $\mathrm{o} \%$ & $100 \%$ \\
\hline Bargaining power of suppliers & $60 \%$ & $40 \%$ & $\mathrm{o} \%$ & $\mathrm{o} \%$ & $\mathrm{o} \%$ & $100 \%$ \\
\hline Threat of substitutes & $\mathrm{o} \%$ & $\mathrm{o} \%$ & $\mathrm{o} \%$ & $20 \%$ & $80 \%$ & $100 \%$ \\
\hline Competitive rivalry & $40 \%$ & $60 \%$ & $\mathrm{o} \%$ & $\mathrm{o} \%$ & $\mathrm{o} \%$ & $100 \%$ \\
\hline
\end{tabular}

Table 7 reveals that $60 \%$ of the respondents ranked the bargaining power of suppliers as most the important competitive force, followed by competitive rivalry. 


\section{Overall Assessment of the Five Forces}

To obtain a final ranking of the competitive forces in the maize milling sector, the values on the strength of competitive forces in Table 6 and values on the importance of competitive forces in Table 7 are combined in Table 8. The combined values for each competitive force are ranked to give the ultimate ranking and evaluation of competitive forces in the maize milling sector in SA.

Table 8: Combined Assessment

\begin{tabular}{|l|c|c|c|c|}
\hline Competitive Force & Strength & Importance & Combined & Ranking \\
\hline Threat of new entrants & 1.6 & $\mathbf{2 . 2}$ & 3.8 & 4 \\
\hline Bargaining power of buyers & 1.8 & 2.6 & 4.4 & 3 \\
\hline Bargaining power of suppliers & 2.8 & 4.6 & 7.4 & 1 \\
\hline Threat of substitutes & 1.4 & 1.2 & 2.6 & 5 \\
\hline Competitive rivalry & 2 & 4.4 & 6.4 & 2 \\
\hline
\end{tabular}

The overall assessment is reflected in Figure 3.

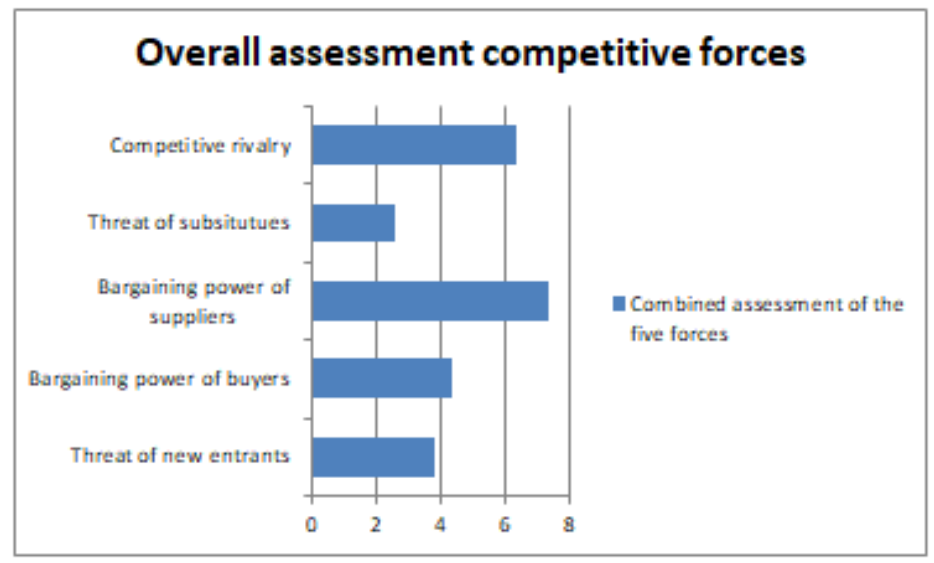

Source: Developed by the Researchers

It is evident from the overall rankings that, the bargaining power of suppliers is the most influential competitive force in the maize milling industry, followed by competitive rivalry and then, the bargaining power of buyers. The threat of new entrants and the threat of substitute products are ranked as being weak and the least influential competitive forces.

\section{Qualitative Data Analysis}

Pparticipants emphasized the importance of stronger relationships with retailers and revealed that the research organization invests on consumer advertising. It was revealed that some of the retailers had private brands which competed with the national brands. However, one participant indicated that their (manufacturer) brands are easily recognized on the shelves, and consumers trust these brands. Furthermore, the research company had more leeway on its marketing spend than the retailers, so it spent more on TV, print and digital advertising. On the other hand, the retailers do not spend much on marketing, and are thus able to keep the costs of private labels down and this benefit accrues to the consumers who enjoy lower prices. 
A participant acknowledged that the company invests on its product diversification strategy, to develop new or improved products, which created a new source of revenue for the company. Furthermore, the 2017 financial statement reflected that the company spent R 771 million on advertising its national brands.

The research organization was established in 1920 and is one of the pioneers of the grain milling sector in South Africa. A participant indicated that the organization has long standing relationships with suppliers of grain milling equipment and raw materials, and in the consumer market, it has substantial brand loyalty among consumers which is difficulty for new entrants circumvent.

Figure 4 depicts the model used by research organization to sustain competitiveness.

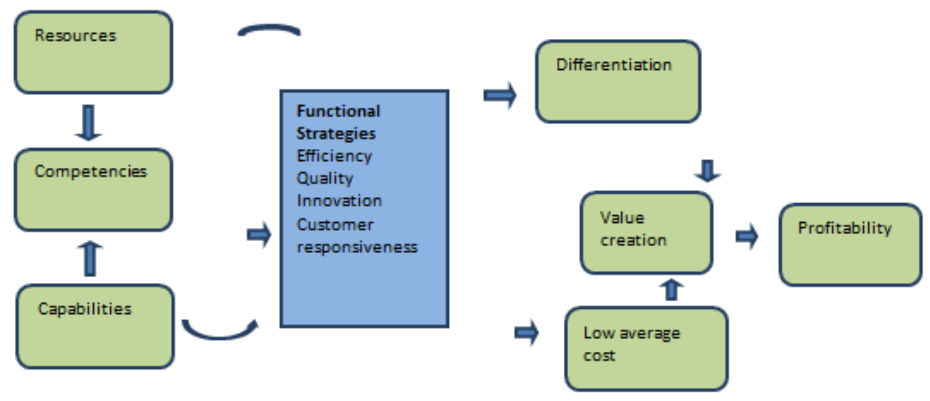

Figure 5: Model for competitive advantage

Source: Adapted by researcher from Hill \& Jones, 2013

\section{Conclusion and Recommendations}

The profitability of an industry is determined by the most influential force, which basically becomes crucial to strategy formulation (Porter, 1980). The high bargaining power of suppliers of grain was identified as the first most influential force affecting competition in the maize milling sector in South Africa. This is so because silo owners often act as traders on SAFEX. The ownership of silos in South Africa is highly concentrated, with only three agro-conglomerates, controlling an estimated $74 \%$ of the national silo capacity $(\mathrm{ACB}, 2013)$.

Competitive rivalry emerged as the second most important force affecting competition in the maize milling sector in South Africa. The large milling firms dominate and shape the nature of competition in the sector because of their influence on the five forces. The maize milling sector is in the maturity phase of the industry evolution and as a result the strategies adopted by the research organization are directed at preserving the market share.

The bargaining power of retailers was identified as the third most competitive force influencing competition in the sector. The study revealed that the research organization focuses attention on growing marketing channels to increase shelf availability. It actively engages retailers to focus on company's products and this is crucial to building market share. At the research organization, emphasis is on growing the marketing channels since this is more difficulty for rivals to imitate in the short run.

The process innovation also enables the research organization to generate more value by reducing production costs. The use of new generation degerminators and milling technology coupled with programmable logic controllers, contributes to the organization's flexible production practices. Flexible production practice allows the research organization to process a variety of maize meal products at a unit cost that is equivalent to the one that could be realized through the large production volume of standardized output. The coordination of production flows between machines is computer-controlled and this results in the reduction of production wastes and work in progress. 
Based on the key findings, the following recommendations are made in relation to maize milling firms, particularly the new entrants in the industry in South Africa.

- Maize milling firms need to recognize their competitive positioning options in relation with their resources and distinctive competencies, as well as their position in the supply and marketing channel.

- Maize milling firms need develop capabilities in building marketing channels.

- Concerning the product strategy, expeditious technological exchange from one organization to another makes it much easier for rivals to achieve parity in product architecture, attributes and quality.

\section{Reference}

African Centre of Biosafety (ACB) (2013). Cartels, Collusion and Control of South Africa's staple food: Report November, pp $18-19$.

Best, N. (2008). Paper T4: Test of professional competence in management accounting. ${ }^{\mathrm{ST}}$ ed. Oxford University Press: Cape Town.

Bureau for Food and Agriculture Policy (2014). Baseline Agricultural Outlook -2014-2023.

Food Price Monitoring Committee (FPMC). (2004). The maize-to-maize value chain, (2)148.

Giannelos, T. (1988). The application of Porter's model to the formulation of competitive strategy for a company in the publishing industry. MBA Degree, The Graduate School of Business, University of Cape Town.

Grant, R.M (1991). The resource-based theory of competitive advantage: Implications for strategy formulation. California Management Review,33(3):114-135.

Grant, R.M (2008). Contemporary strategy analysis. $6^{\text {th }}$ ed. Oxford: Blackwell

Gubrium, F.\& Holstein, J.A. (2001). Handbook of Interview Research: Context and Method. London: Sage

Gurau, C. (2007). Porter's Generic Strategies: A re-interpretation from a marketing perspective. The Marketing Review, 7(4): pp.369-383

Hill, C.W.L \& Jones, G.R. (2013). Theory of strategic management with cases. International Edition.

Mncube, L. (2017). Market access and oligopoly: Food and Agro-processing.

National Agricultural Marketing Council (2011). Factors limiting competition in the agro-processing sector.

Ncube ,P., Nkhonjera ,M., Paremoer, T. \& Zengeni, T. (2016). Competition, barriers to entry and inclusive growth: Agro-processing-working paper 3.

Pitkethly, R. (2003). Analysing the environment. The Oxford handbook of Strategy. New York: Oxford University Press.

Porter, M.E. (1980a). Competitive Strategy. Techniques for analysing industries and competitors. New York: Free Press.

Porter, M.E. (1980b). Industry Structure and Competitive Strategy: Keys to Profitability, Financial Analysts Journal $36(4): 30-41$

Porter, M.E. (1985). Creating and Sustaining Superior Performance. New York: Free Press

Porter, M.E. (1996). What is strategy? Harvard Business Review, 60 - 79.

Porter, M.E. (2008). The five competitive forces that shape strategy. Harvard Business Review, 24-39.

Reddy, C.D (2002). The application of Porter's five forces model to the Nedcor-Stanbic takeover bid. MBA dissertation, University of Witwatersrand, Johannesburg.

South African Grain Information Service (SAGIS) (2016). Maize and Wheat Forum.

Yin, R.K.Z (2009). Case Study Research: Design and Methods, $4^{\text {th }}$ ed, California: Sage 